\title{
A NOÇÃO DE CIDADE NO PENSAMENTO DE ROUSSEAU ${ }^{1}$
}

Jacira de Freitas (Unifesp) ${ }^{2}$

jacirafreitas@outlook.com

Resumo: A discussão desenvolvida no presente texto diz respeito à função conceitual adquirida pela Antiguidade na elaboração do ideal de cidade (cité), no pensamento político de Rousseau. A hipótese a ser demonstrada é que o mito da Antiguidade se transmuta num mecanismo de geração de conceitos que dão sustentação à formulação do seu ideal de corpo político, cristalizado no conceito de cité. Procura-se delinear de que maneira a noção mítica da Antiguidade grega se insere na visão de mundo do jovem Rousseau e, posteriormente, no âmbito de seu pensamento político para elucidar os mecanismos pelos quais interfere na elaboração conceitual do ideal político rousseauniano.

Palavras-chave: Rousseau. Iluminismo. Cidade. Liberdade. República.

Para os intérpretes e especialistas da obra de Jean-Jacques Rousseau não é novidade que a noção de Antiguidade clássica a perpassar o conjunto de sua obra se traduz na expressão mais acabada de sociedades fundadas no princípio da liberdade. Tanto no que diz respeito ao aprimoramento do conhecimento quanto à moralidade das ações humanas ela surge como um momento privilegiado na história da humanidade, razão pela qual oferece alguns pilares a partir dos

\footnotetext{
${ }^{1}$ Recebido: 03-07-2018/ Aceito: 02-12-2018/ Publicado online: 01-02-2019.

2 Professora de Ética e Filosofia Política e História da Filosofia Moderna na Universidade Federal de São Paulo, Unifesp.
} 
quais o filósofo irá construir o seu ideal republicano. Essa concepção se exprime nas constantes referências elogiosas à Esparta e à República romana e na explícita reverência às figuras de Licurgo e Solon, os quais emprestam seu perfil à elaboração conceitual do ideal de Legislador, um dos alicerces de sua teoria política. A discussão central aqui desenvolvida parte da problematização da noção mítica de Antiguidade clássica para elucidar as razões pelas quais ela adquire uma posição privilegiada no sistema rousseauniano, já que em função dela serão elaborados os princípios desse pensamento, em particular, os princípios da ética e da política rousseaunianas traduzidos no conceito de cité. Aquela noção mítica se erige em conceito, mais precisamente num instrumento gerador de conceitos imprescindíveis à harmonia do sistema. O texto aqui apresentado dedica-se a delinear as condições a partir das quais a influência exercida pela noção de Antiguidade se instaura e a demonstrar os mecanismos por meio dos quais se elabora, passando de mito a uma construção racional capaz de engendrar os conceitos essenciais ao pensamento político do filósofo iluminista, em particular, na construção do seu ideal de cité.

Ainda que os estudiosos venham discutindo, ao longo dos anos, o problema da Antiguidade no pensamento de Rousseau, há uma questão ainda a ser respondida que nos interessa particularmente: a relação entre o quadro conceitual, a partir do qual suas reflexões e análises sobre a Antiguidade se realizam e a particularidade da sociedade que ele pretende explicar. A indagação a ser feita é sobre a pertinência da transposição de categorias das sociedades antigas para as sociedades modernas. Ao transpor para o século XVIII categorias pertencentes às sociedades de um outro período não se estaria incorrendo num anacronismo? Trata-se, portanto, 
de apreender de que maneira o pensamento de Rousseau realiza aquela transposição - se é que de fato a realiza - para responder a tal indagação.

Um dos modos de examinar a questão é considerar a estreita relação entre a autobiografia e a obra teórica do filósofo. Alguns intérpretes, dentre os quais Starobinski (1991), debruçaram-se sobre o tema do entrelaçamento entre a vida e a obra de Rousseau, iluminando nosso percurso investigativo. Todavia, é preciso advertir que, na perspectiva aqui adotada, não se trata de saber em que medida se dá a impregnação da obra pela personalidade do autor, mas captar mais de perto o processo de elaboração conceitual do ideal de cidade, no interior do seu pensamento. Para isso é preciso determinar se, e em que condições, a elaboração de constructos teóricos que dão sustentação ao seu pensamento político é influenciada por forças externas, como os elementos socioculturais de sua época, ou internas, tais como aquelas engendradas pelas experiências individuais. Por essa razão, aqui se propõe a análise a partir de uma dupla perspectiva: considerar não apenas os textos em que suas doutrinas são expostas, mas detectar nos textos autobiográficos passagens que permitam explicitar o processo de elaboração daquela noção. A escolha dessa estratégia não significa desconsiderar a influência que pode ter exercido sobre o autor o intercâmbio de ideias ou tendências filosóficas de sua época. Mas, se é inegável a importância do contexto cultural no qual suas ideias se desenvolvem, também é certo que o filósofo genebrino nem sempre está de acordo com as ideias que permeiam o pensamento das Luzes francesas. De modo que, considerar sua obra na perspectiva da inserção numa corrente filosófica poderia restringir sua autonomia de pensamento e deformá-lo à luz do contexto histórico e filosófico. 
Há ainda outra questão metodológica a ser resolvida que nos diz respeito mais diretamente: o problema da articulação entre as experiências pessoais do filósofo na formulação do seu ideal republicano de cité e a concepção teórica dessa noção de corpo político, tal como se constrói nos escritos de doutrina. Tal vinculação seria pertinente ou se configuraria num empecilho à elucidação do ideal republicano, já que ao supor a estreita união entre os dois diferentes registros instaura-se a possibilidade do deslocamento para o plano da afetividade, ao qual as memórias da infância se reportam.

A resposta a essas indagações - e aqui tanto a problematização quanto as análises de Baczko acerca de outro tema nos servem de inspiração - deve levar em conta tanto o aspecto objetivo de conceitos logicamente articulados, quanto o subjetivo relativo a conteúdos psíquicos subjacentes ao discurso, sobretudo nos textos autobiográficos. A construção de um discurso supõe não só conteúdos articulados de forma racional e lógica, a partir de um quadro conceitual, mas também conteúdos que tendem a permanecer encobertos. A dificuldade é que enquanto em seu aspecto objetivo, o discurso é suscetível de uma interpretação filosófica, em seu aspecto subjetivo, isso não ocorre, pois os diferentes contornos adquiridos pelo discurso podem dificultar o trabalho do intérprete. Uma saída talvez seja fazer uma concessão ao próprio filósofo na interpretação de suas experiências internas e fatos objetivos de sua história de vida, pois isso permite ir além da exterioridade dos fatos e da causalidade que os conecta.

Para explicitar as passagens que traduzem a concepção de Rousseau sobre a Antiguidade clássica e sua influência na construção da noção de cité é preciso considerar que, para 
ele, os conteúdos da consciência e as experiências de sua própria vida têm uma importância decisiva para a compreensão de sua obra (STAROBINSKI 1991, 193). Essas experiências integradas à sua concepção de mundo e ao núcleo de referência conceitual de seu pensamento exprimem a particularidade de suas concepções, precisamente o que foi definido por K. Mannheim (1972, 53) como Aspektstruktur: toda visão de mundo se constrói de maneira seletiva e se faz em função do lugar da fala e da percepção da realidade. Será essa a chave de interpretação aqui proposta, pois ela permite um exame da obra suscetível de evidenciar como o quadro conceitual - a partir do qual as experiências do filósofo são articuladas -, está ligado à sua própria visão de realidade; e, por outro lado, traduz como essa visão se exprime na obra por meio de suas teorias. Esse será precisamente nosso ponto de partida na análise do ideal de cité em sua relação com a noção de Antiguidade clássica, tal como se elabora na obra de Rousseau.

É fato reconhecido que a idealização da Antiguidade grega se esboça muito cedo no espírito de Jean-Jacques, conforme as descrições e reconstruções de suas próprias memórias nas Confissões e outras obras autobiográficas, o que traz à tona o problema da verossimilhança do discurso autobiográfico. É preciso responder à indagação sobre a possibilidade de exprimir a verdade sobre si mesmo. Nas Confissões, Rousseau reivindica para si o privilégio de julgar suas próprias experiências. E se ele coloca o "olhar do outro" sob suspeita, como se fosse impotente para chegar à verdade, é porque aquele olhar, aqui sinônimo de julgamento, se constrói por meio de juízos elaborados pelo entendimento fora da própria experiência. É preciso fazer coincidir aquele que conhece as motivações das ações porque as sente e aquele 
que as julga. Eliminando-se o distanciamento entre as duas diferentes instâncias - sensações e entendimento - não há como impedir que a verdade venha à tona. Os acontecimentos de sua consciência e sua vida pessoal terão uma importância decisiva para a compreensão de seu pensamento, mas, sobretudo, a articulação estabelecida entre eles pelo próprio sujeito. Nesse aspecto, Rousseau mantém sua fidelidade à recusa das mediações que reaparece em toda a obra.

Antes do exame do quadro conceitual que viabiliza a articulação das experiências pessoais do filósofo com os aspectos teóricos de suas doutrinas, na reconstrução da Antiguidade clássica, vejamos algumas passagens da obra do filósofo, nas quais já se esboça o ideal de cité e de virtude cívica. Nos Diálogos, falando de si mesmo na terceira pessoa, o filósofo assinala a importância para sua formação do contato ainda na infância com a obra de Plutarco: “Os homens ilustres de Plutarco foram sua primeira leitura em uma idade em que raramente as crianças sabem ler. Os traços desses homens antigos fizeram nele impressões que jamais puderam ser apagadas" (ROUSSEAU 1995a, 819, tradução nossa). O universo heroico da Antiguidade surge, em suas descobertas da infância, pelas mãos da figura paterna, cujo empenho em apresentar-lhe as obras clássicas parece ter sido decisivo na construção das primeiras noções de ética e virtudes morais, como podemos ler num dos mais belos textos da Dedicatória do Discurso sobre a Origem e os Fundamentos da Desigualdade entre os Homens:

Que me seja permitido citar um exemplo do qual deveriam restar vestígios mais firmes e que estará sempre presente em meu coração. Nunca deixo de lembrar-me, com a mais agradável emoção, da memória do mais virtuoso cidadão a quem devo a luz e que, frequentemente, alimentou minha infância com o respeito que vos era devido. Eu o vejo ainda vivendo do trabalho de suas mãos e alimentando sua 
alma com as mais sublimes verdades. Vejo Tácito, Plutarco e Grotius misturados à sua frente, com os instrumentos do ofício. Vejo a seu lado um filho querido recebendo, com frutos bem parcos, as instruções ternas do melhor dos pais. Se os desvarios de uma juventude louca me fizeram, durante um certo tempo, esquecer lições tão sábias, tenho a felicidade de, por fim, demonstrar que ainda que se tenha alguma tendência para o vício dificilmente ficará perdida para sempre uma educação na qual o coração estiver presente (ROUSSEAU 1978, 222).

O que está em questão é a absorção de valores éticos e culturais propiciada não só pela leitura das obras pelo pai3, como também por sua habilidade em transmiti-los a uma criança de tenra idade. Pode-se indagar se é possível associar o pensamento político de Rousseau à sua formação inicial presidida pelo pai, nos primeiros anos de vida, que trouxe ao seu convívio os autores clássicos. Não há dúvida que obras como a Vida de Homens Ilustres de Plutarco e a obra do historiador do Império romano Tácito estão entre aquelas que mais influenciariam o pensamento do filósofo. As constantes referências aos antigos no conjunto da obra rousseauniana não deixa dúvida que aquelas obras encontram-se assim como o Direito da Guerra e da Paz, de Grotius, dentre outras - na raiz das reflexões que deram origem às suas concepções políticas. Todavia, se a Antiguidade clássica adquire tal status em sua obra, isso não pode ser atribuído unicamente à experiência acima mencionada.

A imagem da cidade ideal, inspirada em Esparta e na

\footnotetext{
${ }^{3}$ Além dos estudos clássicos acerca do tema da formação do homem grego, como Paidéia de Werner Jaeger, dispomos hoje de notáveis reflexões sobre a influência dos mitos na formação do homem em estudos etnográficos e antropológicos. Uma Arqueologia da Violência e A Sociedade contra o Estado de Pierre Clastres mostram o papel dos xamãs das sociedades "sem Estado" na divulgação dos mitos, no âmbito de sua própria comunidade. Essas reflexões e as descrições que as inspiram elucidam de que maneira os mitos operam na formação da mentalidade daqueles povos e na inserção cultural da criança em seu universo social.
} 
República romana se elabora também a partir de uma dificuldade detectada na própria vida cotidiana: o problema da incorporação do indivíduo na ordem social existente em razão da ausência de ideais e valores comunitários, substituídos que foram pelo egoísmo. Dentre as passagens da obra em que essa ausência é explicitamente formulada está aquela que mostra a percepção do Emílio da ausência de virtudes e do pathos cívico em sua época, quando da comparação entre seu próprio século e a Antiguidade. É a percepção da falta daqueles valores, nas sociedades ocidentais modernas, que conduz o filósofo a buscar conteúdos que possam exprimi-los o mais fielmente possível. Temos assim uma construção simbólica para aprimorar as imagens projetadas sobre aquele ideal: Esparta e Roma lendárias e as figuras de Cícero ou Diógenes Laércio, Catão e Licurgo fornecem os elementos para clarificar o ideal de cidade e de cidadania.

As reflexões de Baczko sobre liberdade e utopia nos ajudam a pensar 4 a dinâmica dessa construção simbólica (BACZKO 1974, 392). A ausência daqueles valores na vida cotidiana, percebida como uma forma de privação, transforma-se em aspiração à liberdade e à felicidade em função dos conteúdos fornecidos pela Antiguidade. "Com ef eito, quando o homem não aceita sofrer a opressão, a miséria, a injustiça, e busca reconhecê-las e defini-las, ele recorre às ideias e às imagens de liberdade, de felicidade etc" (BACZKO 1974, 392, tradução nossa). O anseio de uma sociedade justa, na qual a liberdade seja possível funda-se assim numa "afecção da alma" que se exprime como uma "evidência primeira" (BACZKO 1974, 390): a impossibilidade de uma existência autêntica num mundo injusto e

\footnotetext{
${ }^{4}$ A ideia é pensar o mito da Antiguidade a partir das reflexões propostas pelo intérprete.
} 
opressivo. O sentimento de privação conduz assim aos anseios nutridos pelos conteúdos fornecidos por outra época. A Antiguidade representa simultaneamente a possibilidade de concretização daqueles valores e a saída do âmbito da pura subjetividade. Os valores universais são agora articulados com aqueles da experiência individual.

Com os valores supremos, que não existem socialmente senão traduzidos em ideias e imagens, juntam-se à experiência individual todo um conjunto histórico de sonhos e mitos coletivos, paradigmas de pensamento, discursos etc. Mas as experiências, mesmo sendo pessoais veiculam certas necessidades coletivas (BACZKO 1974, 392).

O intérprete mostra que, limitados à experiência individual, aqueles valores conduziriam a uma visão parcial da realidade; mas, elevados ao patamar das ideias podem aglutinar projetos individuais e experiências diversas, tornando-se um núcleo de referência de projetos coletivos. A experiência individual é assim integrada a um conjunto de aspirações coletivas, dentre as quais aquelas que se traduzem em ideais supremos, como as ideias de liberdade e felicidade. Mas é preciso definir sob que condições ocorre a elaboração de tais projetos, como aquele da idealização da Lacedemônia.

O embrião do mito da Lacedemônia surge na Antiguidade, sendo concebido pelos próprios espartanos. Concebida no século $\mathrm{V}$ pelos aristocratas atenienses, e, sobretudo, pelos filósofos, a lenda de Licurgo é reelaborada e transmudada pelos espartanos. Embora filósofos como Sócrates, Platão, Aristóteles, os cínicos, os estoicos e os pitagóricos, que viam seu mestre como "um discípulo da sabedoria espartana”, já influenciassem o imaginário coletivo a esse respeito e oferecessem material para a idealização da Lacedemônia, 
o fato é que o mito somente atinge seu ápice e adquire contornos mais definidos com Plutarco e sua obra Vida de Licurgo.

Em La Fascination spartiate (LEDUC-FAYETTE 1974, 72), ao retraçar a gênese do mito espartano e o encantamento que ele exerce até os tempos modernos, Leduc-Fayette observa que o mito espartano exerce a "fascinação de um espelho". De fato, uma das maneiras de pensar o papel decisivo dos mitos na reelaboração do real, particularmente tal como são estudados pela etnologia e pela psicanálise é considerar a "metáfora do espelho". Mesmo sem a pretensão de dar conta da complexidade suscitada pelo tema, é preciso reconhecer que essa metáfora pode contribuir para elucidar a questão dos mitos como instrumento para pensar a própria condição de existência do homem.

Algumas pistas para elucidar o intricado processo de construção da cidade ideal, levando-se em conta a relação especular, parecem surgir5. A primeira delas, indica que o espelho é, antes de tudo, um fenômeno de demarcação de fronteiras entre o imaginário e o simbólico. A segunda revela que a experiência especular nasce do imaginário (ECO 1989, 12). Seguindo por essa via, a Esparta concebida por Rousseau pode não corresponder minimamente à realidade histórica concreta, mas a uma imagem delineada pelo poder criativo da imaginação. Por último, se, por princípio, o espelho apenas "registra aquilo que o atinge da forma como o atinge”, então ele é incapaz de interferir na percepção do objeto ou atuar sobre nossos julgamentos acerca dele (ECO 1989, 17). Estar diante da "Esparta-espelho" não conduzirá

\footnotetext{
5 Tais pistas foram concebidas a partir de reflexões suscitadas pela leitura de um ensaio de Umberto Eco: Eco, Umberto. Sobre os espelhos e outros ensaios. Trad. Beatriz Borges. Rio de Janeiro: Nova Fronteira, 1989.
} 
necessariamente à percepção de nossa real condição social. Também não há garantia que ela possa contribuir para emitir juízos acerca das transformações sociais necessárias para a concretização de um novo modelo de relações sociais. Cabe então indagar qual a sua função metodológica no interior do sistema do filósofo, se afinal não há garantia que ela possa refletir a imagem do mundo tal como ele é; ou ainda, se não é possível ver através dela a sociedade que se deseja ter.

Assim como o espelho não produz a duplicação do objeto, mas apenas reflete o desdobramento da imagem (ECO 1989, 20), a Esparta mítica não é a duplicação da Esparta histórico-concreta, mas tão somente um desdobramento daquela, uma configuração simbólica. Se, por um lado, ela carece de realidade no mundo físico, por outro, sendo uma construção mental ela se erige em ideia. Alçada ao patamar das ideias ela pode cumprir, no interior do sistema de Rousseau, um papel análogo àquele que terá o contrato social, no âmbito dos princípios do direito político: tornar-se, no âmbito das relações sociais efetivas, uma escala a partir da qual se poderá avaliar o índice de degeneração de toda e qualquer sociedade, como propunha Nascimento (1988) a propósito do contrato social. Portanto, não há qualquer relevância em saber se a verdadeira imagem da Lacedemônia é deformada pela lenda, o que, aliás, parece ocorrer, já que os admiradores da cidade dória a concebem em função de seus ideais pessoais, como Platão, que vê nela o símbolo do Estado ideal em sua República, e Diógenes, que a define como o último lugar da vida segundo a natureza.

A Esparta de Rousseau se delineia a partir das descrições de Plutarco. O filósofo a reconstrói a partir de seus anseios pessoais aliados às suas preocupações teórico-políticas. $\mathrm{O}$ 
mito espartano recebe agora uma nova especificação e adquire os contornos de um modelo, no qual a organização política da sociedade não pode se constituir em vista de normas e instituições exteriores a seus membros. Os laços sociais devem ser formais e racionalizados e equivaler à expressão da lei e da razão. Mas, sobretudo, devem estar impregnados pelo compromisso moral que nasce no interior do indivíduo. Na democracia assim concebida, a forma de introdução do homem no meio social se caracteriza pela sua relação com o outro. $\mathrm{O}$ essencial não é a que se estabelece entre governante e governado ou entre o indivíduo e a autoridade; mas a relação direta que se estabelece entre os cidadãos. Eis o modelo proposto pelo filósofo em suas obras teóricas. Essa é também a representação da Lacedemônia que aparecia em Plutarco. Nas descrições de Rousseau, inspiradas na obra de Plutarco, Esparta é a manifestação mais concreta da polis: uma instituição extremamente eficaz em seus mecanismos de união dos indivíduos para além da proximidade física ou geográfica, os quais se constituem em função do interesse da coletividade.

A unidade política capaz de reunir de tal modo os concidadãos está fundada na efetividade de um vínculo social imbuído de um caráter sagrado. É a proteção dos deuses que garante sua instituição. O caráter "político-místico" da unidade política em que consiste a polis reaparece em Rousseau numa nova roupagem. Já não se trata da proteção dos deuses do Olimpo. O caráter "sagrado" do corpo político adquire um novo sentido, explicitamente formulado em várias passagens ao longo da obra. Dentre elas, a do Capítulo I do Livro I do Contrato Social, no qual o "direito sagrado" da ordem social remete a algo que transcende ao homem, não obstante constituir-se por meio dele e com ele; é no próprio 
homem que se processa a metamorfose em função do social.

Se considerasse somente a força e o efeito que dela resulta, diria: 'quando um povo é obrigado a obedecer e o faz, age melhor ainda, porque, recuperando a liberdade pelo mesmo direito pelo que lha arrebataram, outem ele o direito de retomá-la ou não o tinham de subtraí-la'. A ordem social, porém, é um direito sagrado, que serve de base a todos os outros (ROUSSEAU 1978, 22).

Na Economia Política, o corpo político é considerado "a mais sublime de todas as instituições humanas”, uma instituição por meio da qual é possível "imitar cá embaixo os decretos imutáveis da Divindade" e nos dá a impressão de resultar de uma "inspiração celeste". Esse traço caraterístico do corpo político ideal é corroborado também pela distinção entre associação e agregação efetuada No Capítulo II intitulado "Da Sociedade Geral do Gênero Humano" do Manuscrit de Genève (ROUSSEAU 1964, 282). A agregação se traduz numa aglomeração humana meramente física, a ville; ao passo que a associação é o corpo moral constituído pelos cidadãos. Essa distinção reaparece no Contrato Social formulada nestes termos:

Essa pessoa pública que se forma [...] pela união de todas as outras recebia o nome de cidade e, hoje o de república ou de corpo político", e ele prossegue em nota explicitando o sentido de cidade (cité): "o verdadeiro sentido dessa palavra quase desapareceu nos modernos; a maior parte toma um burgo (ville) por uma cidade (cité) e um burguês por um cidadão; eles não sabem que as casas fazem o burgo (ville), mas os cidadãos fazem a cidade (cité) (ROUSSEAU 1978, 33).

A primeira tem uma forma de aparição concreta e visível; ela se define pelo espaço geográfico que ocupa, enquanto a outra projeta-se para além dele, para um plano não visível, no qual a configuração do corpo político se define em função da solidez do vínculo social entre os componentes 
da totalidade social. Sem pretender discutir aqui o perfil sagrado que essa associação tende a adquirir, sobretudo nas formulações posteriores (penso, por exemplo, nas Considerações sobre o Governo da Polônia) pode-se conjecturar que ele já se anuncia no caráter abstrato da associação e na possibilidade por ela instaurada de ascensão para um outro plano além do meramente físico. A exigência da transposição do ser coletivo para um novo plano revela a peculiaridade de uma instância abstrata, na qual é possível realizar o que não se pode no âmbito da pura materialidade: a plena identificação ao outro enquanto parte integrante de uma mesma coletividade. $\mathrm{O}$ caráter sagrado desse ser moral se institui pela identificação das consciências que se opera no domínio da moralidade. A incorporação de características do mito da Antiguidade na elaboração do modelo teórico, como aqui ocorre com o caráter sagrado do corpo político, também corrobora a tese de que conceitos essenciais do pensamento político do autor surgem a partir daquela noção mítica.

Para concluir provisoriamente os desenvolvimentos até aqui realizados, é preciso dizer que a inspiração da Antiguidade não se exprime unicamente na metáfora da Esparta como espelho ou na função metodológica que adquire a Antiguidade, no interior do sistema, já que ela é o "lugar" como afirma Goldschmidt $(1974,119)$ - que marca a distância entre Rousseau e seu século, explicitando as aspirações de sua época. Mas aquela "inspiração" está dispersa ao longo de toda a obra rousseauniana nas exposições e discussões acerca das ideias de Xenofonte, Platão, Plutarco, Sêneca e Tácito, passagens, aliás, que mereceriam um estudo à parte.

A reconstrução do ideal de cité operada por Rousseau 
contrapõe ainda Esparta à Atenas. A cidade de Péricles é descrita como um símbolo da corrupção, pois nela o cultivo das ciências e das artes se faz acompanhar da perda das virtudes éticas e militares e consequente surgimento dos vícios. Exagero de Rousseau? Vejamos. A configuração que ela adquire na crítica de Rousseau é a de uma cidade refinada, marcada pela elegância dos trajes e pela substituição das qualidades guerreiras e morais pelo discurso.

Atenas tornou-se a moradia da polidez e do bom gosto, o país dos oradores e dos filósofos; lá a elegância das edificações correspondia à da língua; viam-se, em todas as partes, o mármore e a tela animados pelas mãos dos mestres mais hábeis. De Atenas saíram essas obras surpreendentes que serviram de modelo a todas as épocas corrompidas. O quadro da Lacedemônia é menos brilhante. 'Lá', diziam os outros povos 'os homens nascem virtuosos e o próprio ar do país parece inspirar a virtude (ROUSSEAU 1978, 339).

Diante do espírito de coletividade e do ideal de simplicidade dos costumes dos cidadãos espartanos e seu menosprezo pelo luxo e pela ostentação, além de tantas outras qualidades atribuídas a este povo, os atenienses destacam-se apenas pela filosofia, o que, aliás, não parece ter uma conotação tão favorável. A célebre afirmação do filósofo, segundo a qual "os atenienses tornaram-se bons apenas em filosofar" reforça essa ideia. Por conseguinte, a indagação a ser feita deve ser acerca das razões da rejeição de Atenas como modelo. A cidade de Sócrates não deveria ser prestigiada por aquele que se dedica tão intensamente à filosofia? $\mathrm{O}$ problema está no fato de Atenas locomover-se na direção do universo da "perversão representativa", - expressão cunhada por Salinas, em seu Paradoxo do Espetáculo - um estágio intermediário que conduzirá, nas etapas subsequentes, aos fenômenos da alienação visados na crítica à civilização 
do segundo Discurso. Ela representa um momento da história da humanidade: aquele que consagra a irremediável viagem rumo ao universo em que as necessidades se ampliam e o ego se expande, sem qualquer possibilidade de volta ao estado de equilíbrio e independência: equilíbrio entre as necessidades e a capacidade de satisfazê-las; independência relativamente à opinião pública e ao "furor de distinguirse”. Sem o saber, os atenienses vão ao encontro de seus grilhões. Péricles, o legislador ateniense, pelo menos aos olhos de Rousseau, não teve êxito em sua tarefa de consolidar a polis.

Os fenômenos implicados na degeneração da civilização e denunciados por Rousseau dizem respeito a realidades sociais relacionadas ao mundo das aparências, ilustradas nas célebres cartas da Nova Heloísa escritas por Saint-Preux em Paris. Nessas descrições, o mundo social se traduz numa sociedade de indivíduos autônomos cuja ação é pautada por interesses pessoais antagônicos. A relação qualitativa do homem em relação ao outro e em relação às coisas é suprimida e as aspirações e metas da ação humana são traduzidas em cifras e grandezas abstratas. A sociedade parisiense se contrapõe diretamente, nessa obra, ao outro modelo que nela se delineia: uma comunidade de economia predominantemente agrícola, autossuficiente economicamente, na qual a função da moeda é excluída ao máximo. Essa exigência de supressão do dinheiro está fundada na intrínseca ligação entre o plano moral e o plano econômico: "[...] só pode haver independência da consciência apoiada e assegurada por uma independência econômica" (STAROBINSKI 1991, 115). Essa forma de autonomia surge como condição para a corporificação do ideal de sociedade fundado na liberdade, único capaz de garantir a felicidade humana. No Livro II do 
Emílio, um ser é feliz quando pode bastar-se a si mesmo. O ideal de autarquia torna-se, assim, o pressuposto para a realização da felicidade pública. A necessidade de eliminar tanto quanto possível a circulação da moeda tem sua origem não apenas na preocupação em impedir que o dinheiro deforme as relações entre os homens e as subverta, mas ainda em restabelecer o equilíbrio entre necessidades e forças, existente no estado primitivo, no qual o homem podia satisfazer por si mesmo suas necessidades. Esse equilíbrio, aliás, é condição para a liberdade; em uma das acepções do termo em Rousseau, ser livre é não estar submetido a nada exterior a si mesmo. Os fenômenos da alienação estão assim vinculados diretamente ao tema do dinheiro e da economia monetária e mercantil. Starobinski já enfatizava - em sua prestigiada obra sobre o pensamento de Rousseau - o ingresso no mundo da aparência como consequência e causa das transformações econômicas e nos advertia sobre a profunda ligação do problema moral e o econômico.

$\mathrm{E}$, enquanto a razão se aperfeiçoa, a propriedade e a desigualdade se introduzem entre os homens, o meu e o teu se separam sempre mais. A ruptura entre ser e parecer passa a marcar o triunfo do "factício", a distância cada vez maior que nos afasta não apenas da natureza exterior, mas de nossa natureza interior (STAROBINSKI 1991, 39).

De fato, segundo as análises de Rousseau, quando os objetos são identificados aos interesses egoístas dos indivíduos, esses se veem isolados cada um em seu amor-próprio, excluindo-se assim toda a possibilidade de realização do ideal coletivo. Há ainda, um movimento de saída de si impulsionado pelo ego narcísico, quando o homem busca nos objetos interpostos entre ele e o outro a essência de si mesmo. Tais movimentos de separação - de si e do outro - que se encontram na raiz do esfacelamento do corpo social e do dilaceramento 
da alma humana são regidos e regulados pela imaginação em seu aspecto criador. Essa faculdade da representação age sobre os sentidos de modo a amenizar ou ampliar as paixões; sendo mais suscetível à sensibilidade moral do que à sensibilidade física 6. O amor-próprio por ela suscitado se faz acompanhar da expansão dos desejos, já que ao atuar simbolicamente sobre os objetos pode transmuda-los, tornandoos ainda mais atrativos. Eis a razão pela qual, no Emílio, assegurar que a própria natureza possa ordenar as paixões é, antes de tudo, orientar a imaginação para objetos em conformidade com tal objetivo, para evitar o desencadeamento de "forças demoníacas, tenebrosas que ofuscam e desnorteiam o coração humano", para usar as palavras de Eigeldinger (1962, 48). Observa-se aqui a importância atribuída por Rousseau ao aspecto psicológico da imaginação - deixando em segundo plano, por exemplo, o aspecto artístico na construção de um mundo irreal e mais atrativo, capaz de suscitar a ampliação das necessidades humanas e a expansão dos desejos. É nesse contexto que se inserem as análises rousseaunianas sobre a importância de se orientar com sabedoria as influências por meio das quais essa faculdade deve ser estimulada. Para neutralizar eventuais ef eitos desfavoráveis ao desenvolvimento da moralidade das ações humanas, é preciso que ela tenha diante de si estímulos voltados para a formação do caráter, da consciência da igualdade social em detrimento da rivalidade e da competição, e, por fim, do desapego de bens materiais que impliquem a distinção em relação aos parceiros sociais. Por essa razão, a escolha das

\footnotetext{
${ }^{6} \mathrm{~A}$ atuação da imaginação sobre os nossos sentidos é inversamente proporcional à intensidade das sensações: quanto mais tênues, maior o predomínio da imaginação sobre elas, conforme o Livro II do Emílio.
} 
leituras tem uma importância decisiva na formação da personalidade do indivíduo. Somente as épocas históricas suscetíveis de inspirar um modelo moral favorável à instituição de sociedades igualitárias e livres podem contribuir para a educação do Emílio, para formar o cidadão. Esse modelo será encontrado por Rousseau nas sociedades da Antiguidade que encarnam o seu ideal de virtude cívica e de simplicidade dos costumes, mais uma vez em Esparta e na República romana, como nos diz o Emílio.

O ingresso no universo simbólico por meio das faculdades intelectuais, como o entendimento e a imaginação, em Rousseau não significa apenas uma aquisição importante do nosso aparelho cognitivo, em virtude da evolução que tais faculdades promovem no plano mental, intelectual e psíquico. Esse ingresso é também pensado como uma perda, levando-se em conta a perspectiva da moralidade das ações humanas. Por isso, adentrar o mundo da representação por meio da atividade da imaginação não significa para Atenas apenas adentrar o mundo das artes e da filosofia, mas submeter-se também ao domínio das paixões que irrompem com a expansão do ego narcísico e seu amor-próprio. Nefastas porque estão na raiz da cisão da personalidade e da diluição dos laços sociais.

Estas conclusões evidenciam a exigência de um novo tipo de relações sociais e apontam também para a contraposição entre dois modos de vida antagônicos: o modo de vida urbano e a vida no campo. Concebida no âmbito da ficção, mais precisamente em um romance epistolar, a comunidade de Clarens da Nova Heloísa traz à tona o tema da recusa da ampliação das necessidades, já mencionado anteriormente. Essa comunidade autossustentável, marcada pela abundância de sua produção agrícola deve seu êxito à simplicidade 
dos costumes e à recusa da ampliação desnecessária das necessidades: "A estabilidade e o equilíbrio da economia se fundam sobre a imutabilidade e inércia das necessidades, que, em Clarens, não mudam e são limitados apenas ao necessário" (BACZKO 1974, 352, tradução nossa). Ao rejeitar o aumento das necessidades e do consumo e prescindir da acumulação da moeda 7, a pequena comunidade instaura as condições para a autonomia moral dos seus habitantes, liberados agora da opressão exercida sobre o indivíduo para acumular bens e buscar distinguir-se dos demais. É a liberação da dimensão do "parecer" que aqui se torna possível. Por meio do modelo socioeconômico do senhor de Wolmar, proprietário de Clarens, Rousseau concebe a possibilidade de uma dupla liberação: a da coletividade e a do indivíduo. A autonomia econômica, engendrada pela satisfação das condições objetivas da existência de cada um dos componentes daquela sociedade se dá simultaneamente à autonomia moral, pela qual se alcança a fruição, que procede não apenas do estreitamento dos vínculos afetivos, mas também da satisfação das necessidades reais em todas as áreas da vida. "Ora, a fruição remete à totalidade da existência humana: ela é autêntica e efetiva com a condição de que nenhum fragmento, nenhuma esfera da existência esteja fora do seu domínio. Com a condição de formar um "todo fechado" (BACZKO 1991, 352, tradução nossa).

Se Clarens parece sempre incorporar elementos do mito da Antiguidade isso não é por acaso, pois, de fato, a Esparta mítica fornece os conteúdos para a formulação do modelo comunitário rousseauniano até mesmo na ficção. Assim

\footnotetext{
${ }^{7}$ Isso não significa que apenas a eliminação da acumulação de capital possa garantir a igualdade; o contraste entre o modelo de relações sociais do Contrato Social e o de Clarens é grande, eles guardam entre si profundas divergências.
} 
como em Clarens, na Esparta concebida por Rousseau, a produção e a satisfação das necessidades estão em conformidade e impedem a introdução do supérfluo e do luxo que romperiam o equilíbrio.

[...] mas se ele idealiza Esparta e Roma republicana é, pelo contrário, hostil à Atenas. Ele não repudia apenas o comércio, a acumulação de riquezas, o refinamento da cultura, mas também e sobretudo seus efeitos sobre o civismo, do individualismo excessivo dos cidadãos que não buscam se identificar ao "eu comum" (BACZKO 1974, 319).

Para ele, Esparta soube manter intactas as qualidades essenciais à vida comunitária, isto é, as virtudes morais e guerreiras e o vínculo entre os concidadãos, ao repelir o acréscimo de falsas necessidades e recusar o luxo dos trajes e a elegância da linguagem. Em consequência do estímulo à prática daquelas virtudes é possível atingir a condição de excelência dos guerreiros da Lacedemônia que a história testemunha. Essa a razão para que os jovens guerreiros espartanos não possuíssem o espírito cultivado. Seu compromisso era com a liberdade da nação. Não se trata de um elogio da guerra - o que aliás, soaria no mínimo contraditório, considerando o teor pacifista do pensamento de Rousseau , ou ainda, uma defesa da hegemonia espartana. O que está em questão é o tema da defesa da nação e sua soberania, cuja importância só pode ser dimensionada à luz do conceito de liberdade política.

Nas Considerações sobre o Governo da Polônia, a eficácia dos exércitos mercenários é questionada, pois somente aquele que se identifica aos demais membros da sociedade e partilha os mesmos valores, costumes e tradições é capaz de defender a nação, já que seu compromisso é tão somente moral. A ideia da guerra como dever cívico já aparecia em Plutarco: defender a pátria não pode ser um meio de ganhar 
dinheiro. Essa é uma tarefa importante demais para ser confiada a exércitos mercenários.

Desde que o serviço público deixa de constituir a atividade principal dos cidadãos e eles preferem servir com sua bolsa a servir com sua pessoa, o Estado já se encontra próximo da ruína. Se lhes for preciso combater, pagarão tropas e ficarão em casa; se necessário ir ao conselho, nomearão deputados e ficarão em casa. À força de preguiça, e de dinheiro, terão, por fim, soldados para escravizar a pátria e representantes para vendê-la (ROUSSEAU 1964, 428).

O risco de esfacelamento do corpo social pela interferência externa só pode ser amenizado ou até mesmo contido pela atuação consistente dos próprios membros da comunidade política. A dicotomia entre o amor-próprio e o amor à pátria contribui para a compreensão da questão, pois enquanto o amor-próprio exprime a perversão das relações entre os indivíduos que, movidos por interesses particulares, tendem a se abandonar aos "afazeres privados" em detrimento do interesse público, o amor à pátria reconduz o homem à esfera da coletividade, e assim fortalece o compromisso moral com seus parceiros sociais. O que Rousseau denomina amor à pátria está também na raiz da superioridade militar e guerreira das nações.

A crença de Rousseau na superioridade militar e guerreira de Esparta aparece ilustrada nesta passagem do Discurso sobre as Giências e as Artes: "Duas famosas Repúblicas disputaram o império do mundo: uma era rica, a outra não tinha nada, e foi essa última que destruiu a outra" (ROUSSEAU 1978, 245). A potência militar da Lacedemônia está associada à rejeição das ciências e da riqueza, por suas consequências perversas sobre o caráter e, por extensão, ao engajamento do cidadão na defesa da sua liberdade e de seus concidadãos: "Se a cultura das ciências é 
prejudicial às qualidades guerreiras, ainda o é mais às qualidades morais" (ROUSSEAU 1978, 347). A fragilidade de Atenas é o caráter mercantil de sua economia, pois a multiplicação das necessidades torna os desejos incontroláveis e os homens gradualmente escravos do supérfluo. A força dos espartanos está em satisfazer-se com o estritamente necessário, preservando-se dos vícios: "Tanto plus in illis proficit vitiorum ignoratio, quam in his cognitivo virtutis.8. Mas, é pertinente perguntar se a atribuição à Esparta de uma tal simplicidade dos costumes não seria exagero do filósofo genebrino. O verbete "Esparta” do Dictionnaire de Trévoux9 já ressaltava a simplicidade dos costumes dos espartanos, de modo que a ideia presente no pensamento do filósofo não era novidade em sua época. Mas é evidente que a defesa da simplicidade dos costumes, à qual Rousseau se aplica, quase não encontra ressonâncias em sua época e em seu meio. Como pretender ter direito a elas no século que, por ser o palco da ascensão da burguesia, encara o comércio e o lucro não apenas como fonte de acumulação de riquezas, mas como condição para a felicidade? "É sem dúvida, porque o século XVIII cultiva o luxo e o refinamento que ele terá horror a essa Esparta frugal que Rousseau defende com paixão" (LEDUC-FAYETTE 1978, 78). A simplicidade nas interações sociais, na aquisição de bens de consumo, na linguagem e em todas as formas de expressão eram consideradas como a antítese do progresso, pelo menos, na visão de Rousseau,

\footnotetext{
8 "Serviu muito mais a estes a ignorância dos vícios do que àqueles o conhecimento da virtude". Citação de Justino (Histórias I, II) inserida na I Parte do segundo Discurso, quando Rousseau ao refutar Hobbes argumenta em favor do caráter pré-moral da condição de existência do homem do estado de natureza.

${ }^{9}$ Dictionnaire universel françois et latin, publicado em Trevoux, em 1704. Trata-se de um dicionário etimológico, cuja primeira edição baseava-se no Dictionnaire universel (1690), de Antoine Furetière. Suas várias edições entre 1704 e 1771 fizeram dele uma fonte importante para a Cyclopaedia (1728) de Ephraim Chambers e para a Encyclopédie de d'Alembert e Diderot publicada entre 1751 a 1772.
} 
que insiste em denunciar o deslocamento do problema da moralidade das ações humanas para o segundo plano. É precisamente esse tipo de razão impotente em contemplar todos os aspectos da existência humana, que é então visada pelo filósofo em sua crítica à civilização. Magnânima quando se trata do conhecimento, das ciências e das artes, a razão iluminista traz em seu bojo o desprezo pela importante discussão sobre o caráter moral das ações humanas na instauração da totalidade social, assim como o pensamento dos atenienses.

Esquecer-me-ia de que foi no próprio seio da Grécia que se viu surgir essa cidade tão célebre pela sua feliz ignorância quanto pela sabedoria das leis, essa república antes de quase-deuses do que de homens, tanto suas virtudes pareciam superiores à humanidade? Oh! Esparta, eterno opróbrio de uma doutrina vã! Enquanto os vícios levados pelas belas-artes se introduziam conjugados em Atenas, enquanto um tirano lá reunia, com tanto cuidado, as obras do príncipe dos poetas, tu escorraçavas para fora de teus muros as artes e os artistas, as ciências e os sábios! (ROUSSEAU 1978, 339).

Não é novidade que filósofos iluministas como Voltaire e Diderot fazem a defesa incondicional da expansão do comércio e engajam-se numa militância a favor do progresso. Essa ideia de progresso supõe um percurso de desenvolvimento da sociedade que passa pela ampliação do comércio, das ciências e das artes. Nas Lettres Anglaises, Voltaire afirma que: "O comércio que enriqueceu os cidadãos na Inglaterra contribuiu para torná-los livres [...] daí resultou a grandeza do Estado" (VOLTAIRE 2011, 30, tradução nossa) enquanto Diderot subordina "a liberdade política à liberdade econômica" no verbete "Homem" da Enciclopédia (D’ALEMBERT 2017). Essa apologia ao progresso entendido como condição de prosperidade e usufruto de bens 
materiais e culturais, conduz, segundo a perspectiva rousseauniana, a uma inversão de valores. Ao posicionar-se contra a corrente progressista do Iluminismo defende que o culto à civilização material conduz necessariamente à degenerescência dos povos e das nações. Mas existe ainda uma outra razão para sua crítica ao progresso.

Um dos fios condutores do Discurso sobre as Giências é a antítese bens materiais versus bens do espírito à qual subjaz aquela entre aparência e essência. A opulência, o luxo e ostentação decretam a ruptura total com a dimensão da Natureza, fundamento metafísico da virtude rousseauniana. Nos fragmentos reunidos na edição da Pléiade sob o título Le luxe, le commerce et les arts se propõe a consideração da questão não mais na perspectiva dos costumes, e sim da prosperidade do Estado. O desprezo nutrido pelos povos da Antiguidade pela suntuosidade, o luxo sendo concebido como sinal de corrupção dos costumes, vinha acompanhado do apreço pela virtude e amor à pátria. Esse sentimento, o qual traduz o movimento de expansão de si na direção do outro, no cuidado com o outro, na priorização dos interesses da coletividade, quando se degenera em amor-próprio, faz o caminho inverso, colocando o eu acima de todo outro: o egoísmo, o orgulho, a avareza e as outras paixões tão nocivas penetram em todas as partes da alma humana. Já não há luxo ou dinheiro capaz de satisfazê-los.

Nessa visão, uma lei parece determinar a história universal: os povos ricos são sempre inevitavelmente conquistados pelos povos mais pobres (ROUSSEAU 1978, Nota IX). Evidentemente, as profundas transformações advindas do desenvolvimento tecnológico nos últimos anos e o poderio militar dele decorrente poderiam comprometer o cerne da argumentação de Rousseau sobre a questão. Não há dúvida 
que o poderio bélico e a indústria armamentista, em nossos dias, atinge dimensões impensáveis para a época dos iluministas. Ainda assim, há exemplos oferecidos pela história recente que favorecem o argumento de Rousseau10. Há que se considerar ainda o reaparecimento do ideal heroico em meados do início do século XX11, como indica Goldschmidt $(1991,122)$. A autoimagem coletiva representada pela figura do herói revigora o sentimento de pertencimento à coletividade e fortalece as instituições. As concepções de Rousseau parecem readquirir seu fôlego.

Mas, é uma outra figura que irá desempenhar uma função central na constituição da cité, por seu caráter excepcional e, de certo modo, transcendente, ao atuar sobre o espírito do povo e transmutá-lo num verdadeiro corpo político: o Legislador. No Capítulo III das Considerações sobre o Governo da Polônia, ele prescreve a instituição de "muitos espetáculos ao ar livre, onde as classes sejam distintas com cuidado, mas onde o povo tome parte igualmente, como ocorria entre os antigos e onde em certas ocasiões a jovem nobreza possa demonstrar destreza e força" (ROUSSEAU 1964, 963). A importância desses espetáculos republicanos está em sua conversão num instrumento potente de transfiguração do homem em cidadão. O Legislador faz uso desses espetáculos para orientar as paixões dos homens e suscitar neles o amor à pátria. Cabe ao Legislador conceber um mecanismo por meio do qual o povo seja o seu próprio educador. Essa formação que o indivíduo impõe a si mesmo pela

\footnotetext{
${ }^{10} \mathrm{Um}$ exemplo a favor do filósofo pode ser encontrados na metade do século XX: a chamada guerra do Vietnã, na qual uma potência bélica mostrou-se incapaz de sobrepujar a força de uma nação pobre e seus defensores movidos pelo sentimento patriótico.

${ }^{11}$ Isso ocorre não apenas no âmbito do pensamento, mas naquele da propaganda política, para nos lembrar que embora o fortalecimento do espírito de uma nação possa corresponder à manutenção de sua unidade e força e para assegurar a liberdade de seus cidadãos, isso não impede a ação opressora dessa nação em relação a outros povos, como ocorreu na Alemanha nazista.
} 
participação em tais ritos patrióticos se dá por meio da interiorização dos princípios supremos da nação traduzidos numa linguagem simbólica. Esses símbolos, ao remeterem às experiências da vida coletiva e aos elementos do seu universo cultural suscitam, ao mesmo tempo, a identificação do indivíduo aos demais e o sentimento de pertencimento àquela coletividade. A aproximação entre os cidadãos, daí resultante, contribui para o aprimoramento da qualidade das relações sociais, fazendo aflorar sentimentos de fraternidade relativamente ao conjunto de cidadãos. Os símbolos representam os valores próprios à nação; a música, a dança e a própria natureza fazem dela um "objeto de culto sagrado" (SALINAS FORTES 1997, 107) O sentimento por ela nutrido implica a renúncia da condição alienante da vida em sociedade, onde reina o amor-próprio e os interesses egoístas. Liberto do "furor de distinção", o indivíduo pode assim se fundir num todo maior que lhe confere plena identidade. Tornar-se cidadão é poder compartilhar os mesmos costumes, tradições e sentimentos que identificam o seu povo.

Há ainda um ponto a ser examinado: a influência exercida sobre sua visão de educação pelas estratégias de formação dos cidadãos da Antiguidade, exame essencial para que se torne inteligível o conjunto de implicações do nosso tema (ROUSSEAU 1964, 259). É preciso enfatizar a primazia da educação na construção da identificação de interesses, costumes e tradições que caracterizam um povo. É por meio dela que se pode desenvolver a consciência de pertencimento a uma coletividade; sua função é "dar às almas o caráter nacional e dirigir de tal modo suas opiniões e seus gostos que elas sejam patriotas por inclinação, por paixão, por necessidade [..] (ROUSSEAU 1964, 966). O segundo ponto diz 
respeito ao tempo exigido e à frequência das ações orientadas para a formação do cidadão: "formar cidadãos não é ocupação de um dia; e para ter homens é preciso instruir as crianças". A educação do cidadão não se dá em um período específico da vida; ao contrário prolonga-se por toda a sua vida. Para que seja cultivada continuamente é preciso recorrer a mecanismos que tornem presente os pilares de cada cultura, povo ou nação, dentre eles, o mais importante é a encenação dos costumes e tradições, como mostra esta passagem, na qual Rousseau sugere que sejam promovidos com frequência espetáculos republicanos.

[...] muitos jogos públicos onde a boa mãe pátria se compraz em ver brincar suas crianças. Que ela frequentemente se ocupe delas a fim de que elas se ocupem sempre dela. É preciso abolir divertimentos vulgares, o jogo, os teatros, comédias, ópera [...] tudo o que os distrai, os isola, os faz esquecer sua pátria e seu dever [..] é preciso inventar jogos, festas, solenidades que sejam tão próprios a essa nação que não sejam encontrados em nenhuma outra (ROUSSEAU 1964, 962).

Fundadas nos princípios fundamentais da nação, suas instituições podem traduzir numa linguagem simbólica "o gênio, o caráter, os gostos e costumes de um povo". E se a exigência de visibilidade da nação orienta a escolha desses espetáculos é porque os traços culturais específicos de cada povo asseguram a unidade, garantindo assim a própria sobrevivência do corpo político republicano, sua liberdade e soberania, daí porque devem ser constantemente revividos.

A atuação do Legislador desloca-se do âmbito da consagração do caráter nacionalpara o da formação do indivíduo em vista da melhor maneira de inseri-lo no corpo político, preparando-o para a vida comunitária. Mas como realizar efetivamente esse plano de formação integral do indivíduo no interesse da coletividade? Mais uma vez, a inspiração 
vem dos antigos. Na polis espartana, tal como concebida por Rousseau, o "eu individual" é superado e se confunde com a totalidade. A admiração por Licurgo se deve precisamente a esta capacidade de garantir a preservação das instituições espartanas por meio da construção de um novo homem despojado do amor-próprio egoísta, consciente da condição de igualdade que possui em relação aos seus concidadãos e do privilégio de formar com eles o corpo coletivo. Ao legislador atribui-se a função de levar o cidadão a não querer, a não conseguir viver em isolamento, nem guiar-se pelo interesse pessoal em detrimento da coletividade na qual está inserido. O verdadeiro legislador é capaz de despertar no indivíduo o anseio de viver efetivamente movido pelo anseio da satisfação das necessidades coletivas. Como as abelhas - da descrição de Plutarco (PLUTARQUE 2001, 25), os cidadãos reunidos ao redor do legislador, também são movidos pela entrega ao seu povo, pelo desejo de cuidar de sua pátria. Em vista desse propósito, a educação deixa de limitar-se apenas ao indivíduo para contemplar também sua relação com a coletividade, já que se trata de fazer aflorar a consciência de que sua existência está condicionada àquela de um todo maior. É essa a instituição pública exaltada pelo filósofo. Compreende-se agora porque a relação fundamental para garantir a coesão social não é a que se estabelece entre governante e governado e sim a relação de cidadão a cidadão.

A resposta à indagação - proposta logo no início do texto - acerca do transporte de categorias relativas às sociedades antigas que seriam projetadas sobre o ideal rousseauniano de corpo político, embora já demonstrada no decorrer do texto, é aqui explicitamente enunciada: o mito da Antiguidade fornece os elementos que serão reelaborados e reinterpretados em função de exigências teóricas e problemas conceituais 
postos por sua filosofia. Não há transposição de elementos da sociedade de uma época para outra pela simples razão que a concepção do corpo político ideal se elabora no âmbito dos princípios e não no âmbito da história.

Por fim, as reflexões políticas acerca da constituição da cité, em Rousseau, envolvem ainda a crítica à propriedade privada. Esparta mais uma vez o inspira e o maior desafio que ela impõe é precisamente a posse comum dos bens. Ainda que a propriedade privada esteja na origem da sociedade civil, mais precisamente na origem dos conflitos que atingem a humanidade, como anuncia a célebre frase do segundo Discurso, Rousseau não irá recusá-la. Pois isso corresponderia a uma mudança radical nas estruturas sociais, o que traria à obra do filósofo genebrino um viés inequivocamente revolucionário, como se houvesse a proposta de mudanças estruturais nas sociedades modernas, como um programa de ação política, quando, na verdade a discussão mais importante é aquela sobre as condições que determinam a degeneração do homem na vida social.

No Discurso, a noção de propriedade está imbricada na noção de trabalho: "é somente o trabalho que dá direito ao cultivador sobre o produto da terra que ele produziu... essa posse contínua, a produção ano a ano se transforma em propriedade" (ROUSSEAU 1964, 173). No Emílio, a ideia de propriedade, uma das primeiras a serem ensinadas ao seu aluno, também é associada à noção de trabalho, pois ela "remonta naturalmente àquela do primeiro ocupante pelo trabalho". Atrelada à noção de trabalho, a propriedade aparece na obra de Rousseau como resultado de uma posse contínua. Mesmo não sendo suprimida, não há qualquer sinal de sua defesa, pelo contrário, o princípio será condenado: nenhuma posse individual é legítima. Isso significa 
que se a vontade geral assim deliberar, a propriedade pode ser suprimida em função do interesse da comunidade. A aguçada percepção do filósofo dos riscos implicados na introdução da propriedade aqui se revela. Por essa razão, quando nos movemos no âmbito dos princípios do direito político, o critério que define o direito a ela estará subjugado aos interesses da comunidade política, e não àqueles dos particulares. A proximidade dos princípios da sociedade espartana mais uma vez aqui se evidencia.

A concepção de igualdade que se exprime nessa interpretação está associada à noção de direito, como se lê no Contrato Social: "Todos os homens nascem iguais e livres", escreve ele. Em Esparta, os omoioi eram considerados como iguais inclusive pela ausência de qualquer riqueza, já que faziam parte de uma casta fechada composta unicamente por guerreiros submetidos a uma rigorosa disciplina e sem permissão de executar outra profissão. "Não se deixava ninguém viver a seu bel-prazer - escreve Plutarco - a cidade era como um campo; cada um se conduzia segundo o gênero de vida determinado pela lei; todas as ocupações tinham em vista a comunidade e se devia saber que tudo pertencia ao Estado" (PLUTARQUE 2001, 24). Se o êxito do legislador espartano depende dos mecanismos de preservação do corpo político que ele concebe, o mais importante dentre eles será sem qualquer sombra de dúvida aquele capaz de garantir a existência e a preservação da propriedade coletiva, pois é disso que depende a igualdade dos concidadãos, base última da consistência da polis. E como a propriedade privada se instaura após a eclosão do amor próprio isso nos permite supor também a antecedência lógica da degeneração moral do homem em relação aos aspectos econômicos que culminam 
na instauração definitiva da desigualdade. Ao atuar na constituição psicossocial do indivíduo, o legislador pode preparar as condições para a introjeção da ideia de propriedade coletiva, ou, pelo menos, para impedir a fixação da ideia de propriedade privada. É disso que depende a possibilidade não apenas da harmonia do corpo político, como também do equilíbrio de forças econômicas que garantirá a igualdade dos cidadãos. Pode-se presumir, seguindo esse raciocínio, que se sociedades como a ateniense se corromperam, isso se deu pela falta de percepção, por parte do legislador, dos riscos impostos pelo amor próprio e de uma medida eficaz para substituir o egoísmo pelo sentimento de pertencimento à coletividade

O que perdeu o gênero humano, o que fez com que o homem abandonasse a felicidade experimentada durante a juventude do mundo, foi a instauração da propriedade que se segue a esse momento do desenvolvimento do amor próprio. Apesar dessa continuidade entre os dois momentos do estado de natureza, Rousseau referia-se à instauração da propriedade privada como uma grande revolução.. Uma vez que a terra havia sido partilhada, a desigualdade entre os homens aumentava e implicava consequência em suas relações. Os que tinham mais talento, ou que eram mais fortes, começaram a enriquecer-se e a abusar de suas riquezas (MARUYAMA 2005, 431).

A propriedade privada representa uma grande revolução em dois diferentes sentidos: ela está na origem do desenvolvimento material da sociedade, já que supõe o aprimoramento das técnicas para usufruir das terras que vão sendo apropriadas, mas é também o que irá deflagrar a desigualdade, engendrando, ao lado da ambição e da rivalidade, a dominação e a servidão. A desigualdade consolidase com a hierarquia fundada na posse privada da terra. A grande revolução representada pela introdução da proprie- 
dade privada permite entrever a distância que separa Esparta de Atenas. No entanto, se as duas cidades-Estados gregas se situam historicamente no mesmo período e se, na reconstrução hipotético-dedutiva oferecida por Rousseau no segundo Discurso, ambas se inserem nas etapas subsequentes ao último estágio do estado de natureza, essa proximidade é meramente ilusória. O ideal comunitário espartano projeta Esparta para um lugar além da história. Esparta está a uma distância inacessível aos atenienses, pois para esses últimos não há volta possível. Uma vez corrompida, a cidade jamais poderá retornar ao seu estado original.

Abstract: The discussion being developed in the following text concerns the conceptual function acquired by the notion of Antiquity in the elaboration of the ideal of a city (cité), in Rousseau's political thinking. The hypothesis to be demonstrated is that the myth of Lacedaemon transmutes into a mechanism of concept generation that sustains the formulation of his ideal of political body, crystallized into the concept of cité. We aim to point in which way this mythical notion is inserted in young Rousseau's world view and, afterwards, in the scope of his political thinking, in order to elucidate the mechanisms through which it interferes in the conceptual elaboration of the rousseaunian political ideal.

Keywords: Rousseau. Enlightenment. City. Liberty. Republic.

\section{REFERÊNGIAS}

BACZKO, Bronislaw. Rousseau: solitude et communauté. Tradução do polonês por Claire Brendel-Lamnhout. Paris: Mouton, La Haye, $1^{a}$ edição, 1974.

BECKER, Evaldo. Política e Linguagem em Rousseau. São Cristóvão: Ed. UFS, 2016.

D'ALEMBERT, Jean le Rond e DIDEROT, Denis. Verbete "Homem". Encyclopédia ou Dicionário razoado das ciências, das artes e dos ofícios. Tradução Pedro Paulo Pimenta, 
Maria das Graças de Souza e Thomaz Kawauche. São Paulo: Editora da Unesp, 2017.

DERATHÉ, R. "La Dialectique du Bonheur chez Jean-Jacques Rousseau", Revue de théologie et de philosophie, pp. 81-96.

DUVIGNAUD, Jean. Sociologie du théâtre. Paris: Quadrige/PUF, $1^{\text {a }}$ ed., 1999.

ECO, Umberto. Sobre os espelhos e outros ensaios. Trad. Beatriz Borges. Rio de Janeiro: Nova Fronteira, 1989.

EIGELDINGER, Marc. Jean-Jacques Rousseau et la Realité de L 'Imaginaire. Neuchâtel: Ed. la Baconnière, 1962.

GOLDSCHMIDT, Victor. Antropologie et Politique - Les Principes du système de Rousseau. Paris: J. Vrin, 1974.

LAUNAY, M. Rousseau: Écrivain Politique. Grenoble: Sel-ACER, 1971.

LEDUC-FAYETTE, D. Rousseau et le Mithe de l'Antiquité. Paris: J. Vrin, 1974.

MANNHEIM, Karl. Ideologie und Utopie, Frankfurt, Vittorio Klostermann, 2015.

MARQUES, José Oscar de Almeida (Org.). Reflexos de Rousseau. São Paulo: Associação Editorial Humanitas, 2007.

MARUYAMA, Natália. A Moral e a Filosofia Política de Helvétius - uma discussão com J.-J. Rousseau. São Paulo: Humanitas, 2005.

MOREL, Jean-Jacques. "Rousseau lit Plutarque". In: Revue d'Histoire Moderne, n'2, 1926. 
NASCIMENTO, Milton M. "O Contrato Social: entre a escala e o programa”. Revista Discurso. São Paulo: Departamento de Filosofia da USP, 1988.

OLLIER, F. Le mirage spartiate. Étude sur l'idéalisation de Sparte dans l'antiquité grecque, de origine jusqu'aux cyniques, De Boccard, 1974. 1933

PLUTARQUE. Oeuvres Complètes de Plutarque. Ouvres Morales et oeuvres diverses traduites en français par Victor Betoland. Tomme II. Paris: Librairie L. Hachete, 1870.

. Vie de Lycurgo. Les vies parallèles. Paris: Ed. Robert Laffont, 2001.

PRADO JUNIOR, B. A retórica de Rousseau. São Paulo: Cosacnaif, 2008.

ROUSSEAU, J.-J. Émile ou de l'Éducation. Chronologie et introduction par Michel Launay. Paris: Garnier-Flammarion, 1966.

. Emílio ou Da Educação. São Paulo: Martins Fontes, 1995 (b).

. Oeuvres Complètes. Paris: Gallimard, Bibliothèque de la Pléiade, v. I (1959), v. II (1961), v. III (1964), v. IV (1969), v. V (1995( a).

. Os Pensadores. São Paulo: Abril Cultural, 1978.

SOUZA, Maria das Graças de. Ilustração e História. São Paulo: Discurso Editorial, 2001.

STAROBINSKI, J. Jean-Jacques Rousseau: A Transparência e o Obstáculo. São Paulo: Schwarcz, 1991. 
TOUCHEFEU, YVES. Rousseau et L'Antiquité. Memoire de D.E.A présenté à L'École des Hautes Études en Sciences Sociales. Paris, 1986.

VOLTAIRE. "Sur le commerce". Lettres Philosophiques, $X$. Édition électronique (ePub) v.: 1,0: Les Échos du Maquis, 2011. P. 30. Acesso: https://philosophie.cegeptr.qc.ca/wp-content/documents/Lettres-philosophiques1734.pdf. 